$$
\begin{gathered}
\text { ヤクーチヤ(シベリア), バロー(アラスカ }), \\
\text { マッケンジーデルタ(カナダ)における } \\
\text { いくつかの典型的な永久凍土地形 }
\end{gathered}
$$

$$
\text { 木下誠 一* }
$$

\title{
Some Typical Landforms of Permafrost at Yakutia (Siberia), Barrow (Alaska) and Mackenzie Delta (Canada)
}

\author{
Seiiti KINOSITA
}

\begin{abstract}
Scientific expeditions in permafrost regions were carried out at Yakutia, Siberia in the middle of August, 1972 and at Barrow, Alaska and Tuktoyaktuk, Mackenzie Delta in the summers of 1974 and 1977.

\section{Yakutia, Siberia}

Field observations were conducted on permafrost around Lake Surdakh, which is located $250 \mathrm{~km}$ northeast from Yakutsk, Siberia. Lake Surdakh is an alas, which is a depression formed by a thermokarst development in which local deep thawing has taken place in permafrost masses accompanied by the melting of ground ice. The shape of the alas is nearly round and the diameter of Lake Surdakh is about $4 \mathrm{~km}$. The lake is surrounded from all sides by a larch forest. The height of the basin cliffs is about $20 \mathrm{~m}$. At some places along the cliffs underground ices are exposed. The top of the ices is $1.5 \mathrm{~m}$ below the top of the cliffs and the ices sink into the ground in a wedge-like shape. Observations were made as to the exposed ice, the soil around the exposed ice and the forest above the ground, and also on the some alases in the vicinity.

\section{Barrow and Tukutoyaktuk}

Field observations were conducted on high center polygons, pingos, ice wedges and exposed massive ground ice, all of which showed characteristic land feature of the tundra area composed of permafrost.

a. High center polygon

Spreading gregariously, high center polygons formed an orthogonal net pattern near Footprint Creek, $3 \mathrm{~km}$ southwest of NARL, Barrow. Each mound was $5-10 \mathrm{~m}$ in width and $50-100 \mathrm{~cm}$ in height. A crack ran along the trough between two neighboring mounds. The surface at the raised center of a mound was covered with vegetations including willow, birch and crowberry. Core samples showed the structures of layers; namely, the upper layer of $5-10 \mathrm{~cm}$ in thickness was composed of mixture of roots,
\end{abstract}

* 北海道大学低温科学研究所

Institute of Low Temperature Science, Hokkaido University 
organic material, and silt, while the layer underneath was composed almost of ice-rich peat, which had such an extremely high water content as amounts to $1000-2000 \%$, the ice being uniformly contained not in the form of ice lenses. Meanwhile, as for the trough, its surface was covered with gramineae or formed puddles, while the layer above the depth of $40-50 \mathrm{~cm}$ was composed of silty soil and contained distinct ice lenses, whereas the layer below this depth was composed of ice, which was polycrystalline with ice crystals several $\mathrm{cm}$ in length and almost stretching vertically. Polygons studied by the authors exemplified the type of ice-wedge polygons.

b. Pingo

The most spectacular landform associated with permafrost in the pingo formed in the shape of a conical hill. More than 1000 pingos have been mapped in the Mackenzie Delta. Some pingos which stands along the sea coast has been eroded by sea waves, some parts being cut open. The pingo is a small mound which has risen as the result of ice segregation taking place inside. It was made clear that some pingos studied had started to rise long before because the ground at the top contained such a driftwood piece, shells and pebbles that exist in the lowland at present. At the top the layer structure of core samples was firstly sand formed by weathering, and secondly silt, and then clay, which was in the form of conspicuous angular clods of clay and contained ice as orthogonal nets. At the crater ice was found at the depth of about $100 \mathrm{~cm}$, which was polycrystalline with ice crystals having almost the same size both in the vertical and horizontal dimensions. At the foot angular clods of clay were also found at some depths.

c. Ice wedge and exposed massive ground ice

A terraced land developed along the sea coast ranging from 4 to $5 \mathrm{~km}$ to the southwest of Tuktoyaktuk PCSP Camp. Exposed along the cliff facing the Beaufort Sea were a massive ground ice body and ice wedges being formed at some intervals between the top of the cliff and the ground ice. The ground ice contained horizontal sand layers at some intervals. The ice structures of the ground ice and ice wedges were polycrystalline with ice crystals having the size as large as $5-10 \mathrm{~cm}$.

文部省科学研究費補助金による 海外学術調査として “シベリア学術調查” (昭和 47 年), “永 久凍土圈学術調査”（昭和 49 年，52年，55年）が行なわれた。この調查は, 物理及び生物の両 面からの総合調査で，その結果については昭和55年度のを除き，既に報告がなされている これらの調査で得られた知見のうち, 特にヤクーチヤ(シベリア), バロー(アラスカ), マッケ ンジーデルタ（カナダ）の永久凍土地域における典型的な永久凍土地形について，その若干を 紹介しよう。

\section{I. ヤクーチヤ (シベリア)}

シベリアのヤクーチヤ（ヤクーツク地方）は，冬の最低気温がー $60^{\circ} \mathrm{C}$ 以下になることもあ

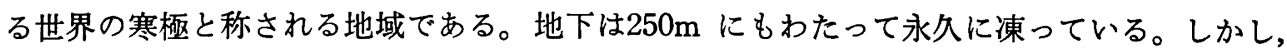
この永久に凍る大地の上にはタイガと云われる大樹林帯が存在する。ヤクーツク市の年平均気 温は $-10^{\circ} \mathrm{C}$ で, 冬期間の積算寒度は $7,000 \sim 8,000^{\circ} \mathrm{C}$ day もある。しかし, 夏,特に 7 月は暑 く, $30^{\circ} \mathrm{C}$ をこすことも稀でない4。永久に凍った地面とはいえ，夏には融ける。勿論冬にな ると凍るが，この夏に融け冬に凍る地面近くの層を活動層と呼ぶ。特にヤクーツク地方のよう 


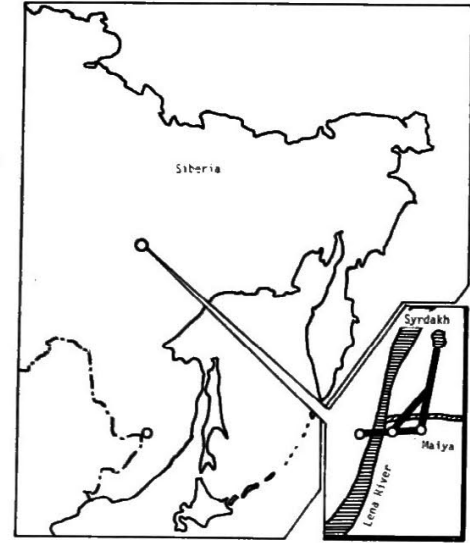

第 1 図調查地点の地図

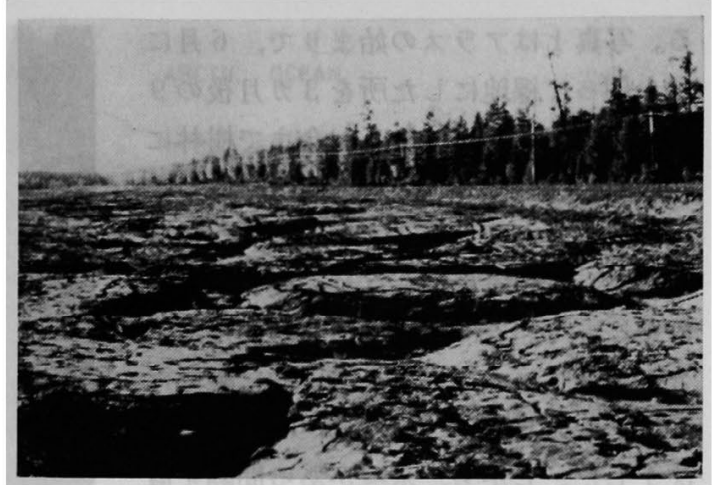

写真 13 カ月前に裸地になった所で, 地面が すでに $1 \mathrm{~m}$ 沈下し，亀甲模様(円形土) が出来ている アラスの始まり

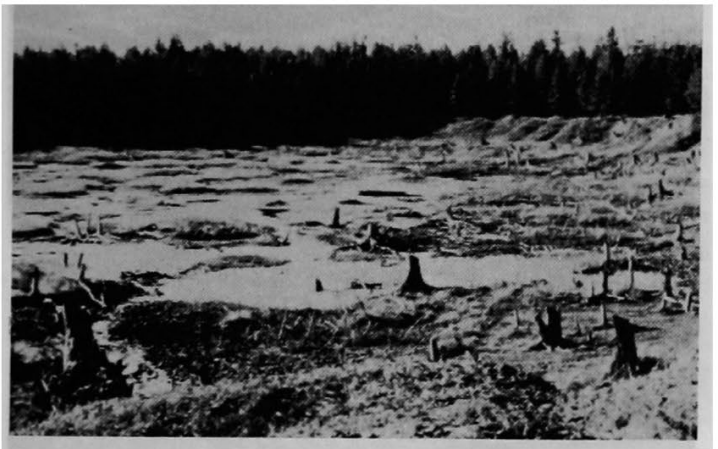

写真 2 40年前に木を切って裸地にした所で, 地面が $2 \mathrm{~m}$ 沈下

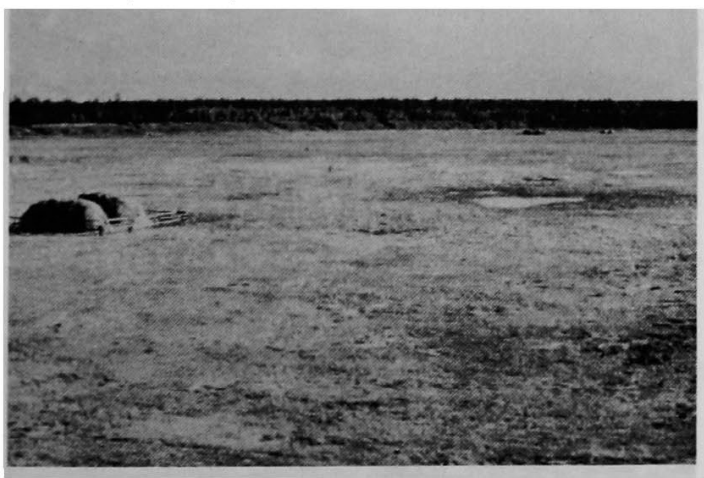

写真 3 直径数百メートルの皿状に凹んだアラ ス, 牧草地である

な内陸は夏に暑く，裸地では $2 \mathrm{~m}$ ほど も融ける。樹林帯のなかでは, 立木密度 が密なほど，活動層の厚さは減る。

年間の降水量は 僅か $200 \mathrm{~mm}$ 前後で, そのうち冬の雪は $35 \mathrm{~mm}$ 前後である。こ の降水量は活動層から下へは洨透して行 かない。従って年間を通じて僅かの降水 量にすぎなくても，それが活動層内に蓄 えられる(地表からの蒸発も勿論ある)。 それが植物の涵養源になる。樹林の形を とる植物は主としてダフリアカラマッと いう針葉樹である5!。立木密度は密林で 1 ha 当り 15,000本位で, 各樹木の太さ は10 15cm，高さ10 15m，樹齡100年 前後で，相互の間隔は $50 \sim 100 \mathrm{~cm}$ の樹 林帯を形成する。これがタイガと呼ばれ るものである。

昭和 47 年の調査において主として対象 となった地域は第 1 図に示されるヤクー ック市から北東約 $250 \mathrm{~km}$ のスイルダッ 八湖周辺である。ここでの典型的な永久 凍土地形はアラスである。

\section{アラス}

アラスは樹林帯のなかにポッンと開け

る皿状に凹んだ裸地である。熱カルストの一種である。

アラスができるきっかけは，木を切るとか山火事などで樹林帯の一部が裸地になることであ 
る。写真 1 はアラスの始まりで, 6 月に 木を切って裸地にした所を 3 力月後の 9 月に撮影したものである。今まで樹林に 被われて，夏の間でも深さ $70 \mathrm{~cm}$ 位しか 融けなかった凍土が，木を切られたため 地面が直接暖気にさらされ，又日射をう けることで，融解が $2 \mathrm{~m}$ にも及んだ。 今まで活動層の下の永久凍土内に融けな いでいた氷が 融け，地面は $1 \mathrm{~m}$ ほども 沈下した。しかも，氷塊がある間隔を置 いて亀甲模様に配置していたため，その 部分が特に沈下し，地面に亀甲模様の凹 みが出来た。このときの凸凹の間隔はほ ぼ10m である。

凹んだ地面も冬には凍る。しかし，又 夏に融け出して再び沈下する。40年もた つと, $2 \mathrm{~m}$ ほども沈下する (写真 2 )。 皿状に凹んだ側面においても夏の融解が 起るので，その上の立木が倒れ，皿状に 凹んだ部分を更に側方へと拡げて行く。 このようなことを繰返すうちに，広さ数 百メートル(写真 3 ) から数 $\mathrm{km}$ にも達す る大きなアラスが出来る。側端面には亀 甲模様の円形構造土が依然として形を残 す (写真 4，5)。深さの方は $10 \mathrm{~m}$ から $20 \mathrm{~m}$ でとまってしまう。

地下の水が豊富な所では，融け水が溜 って湖を作るものがあるが，一般には蒸 発して次第に湖が小さくなって行く。

スイルダッ八湖は，アラスに出来た水 溜りで，直径 $4 \mathrm{~km}$ ほどの円形の湖であ り，その水源は湖岸の崖に露出する地下 水である。この氷が夏に融けて流入する だけで，他には流入する川も流出する川 もない。湖水面からの水の蒸発と地下水 の夏期の融解による流入とがほぼつり合 って，現在では一定の湖水面位を保って いる。地下氷の露出する湖岸は夏期の融 解で $1 \mathrm{~m}$ ほど 後退する。湖の深さは 6

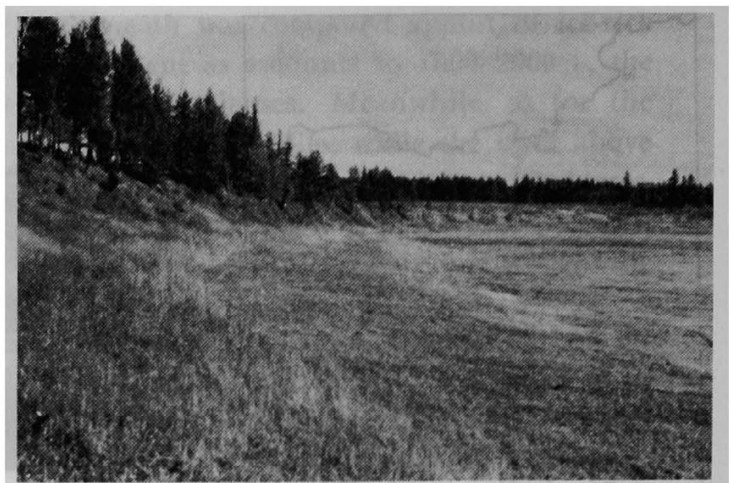

写真 4 直径数百メートルのアラスの側端面

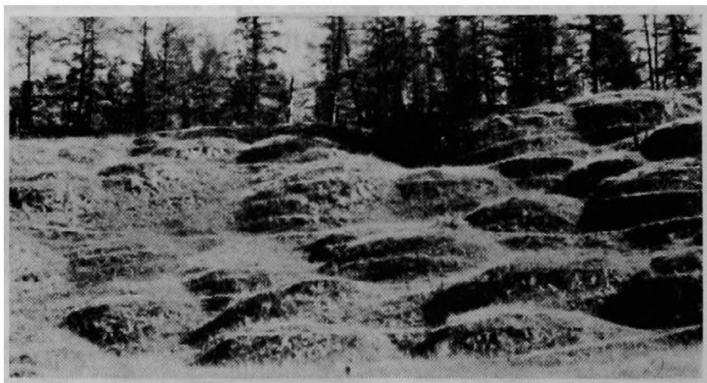

写真 5 アラス側端面に残る円形棈造土

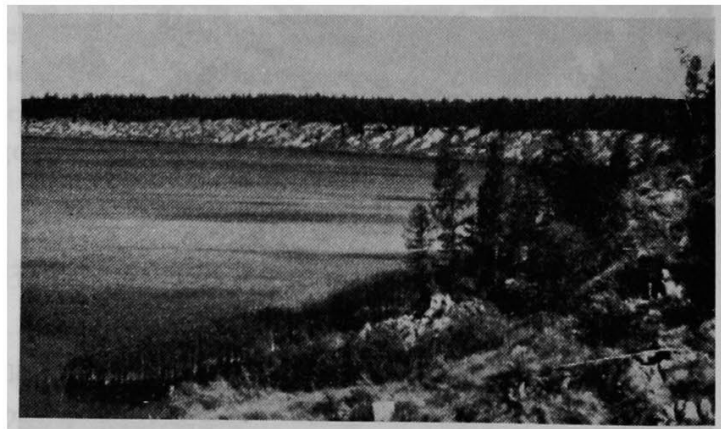

写真 6 スイルダッ八湖，湖岸の高さ $20 \mathrm{~m}$ ，そ の上の樹林の高さ10 15m

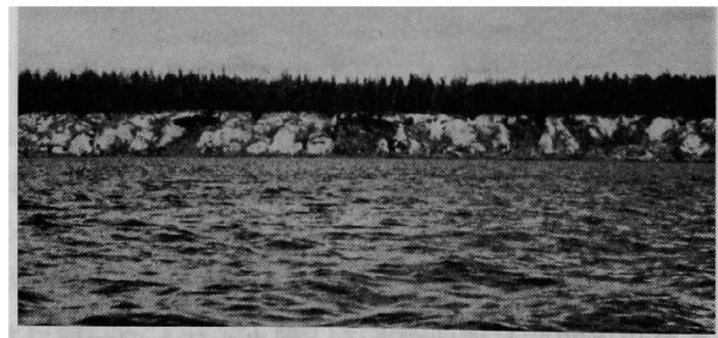

写真 7 スイルダッハ湖，湖岸に地下水が露出 して融解しているのが見える 


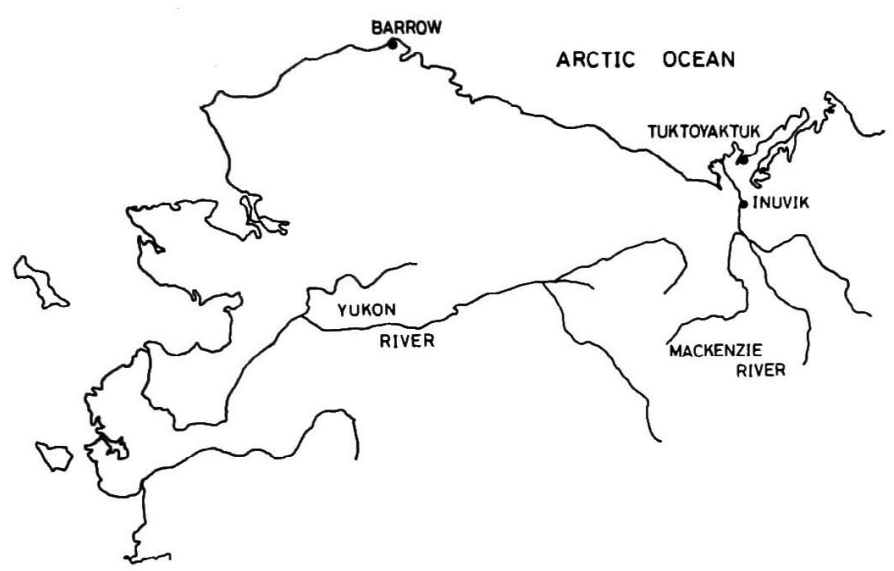

第 2 図 バローとタクトヤクタークの地図

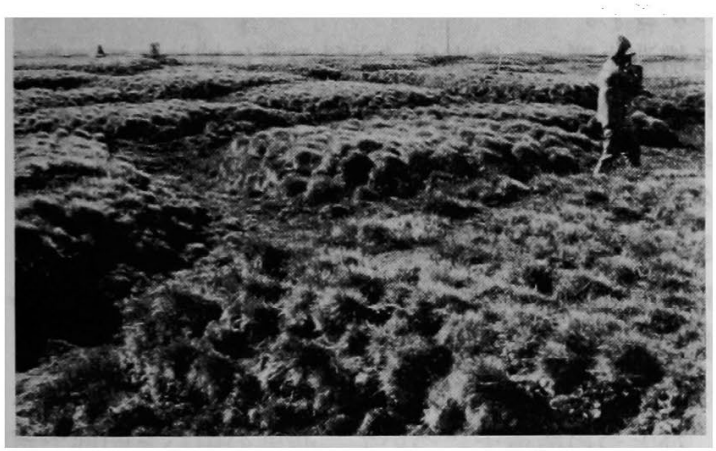

写真 8 バローにおける構造土

$\mathrm{m}$, 湖の底は $2 \sim 5 \mathrm{~m}$ 融解した土であるが，その 下には250m もの厚い永久凍土が続く。勿論湖水 は冬には凍る。10月始めには凍り始め, 厚さは $2 \mathrm{~m}$ 以上にもなる。春になって完全に水が融ける のは 6 月にもなるということである。

\section{II. バロー(アラスカ), マッケンジーデルタ のタクトヤクターク周辺(カナダ)}

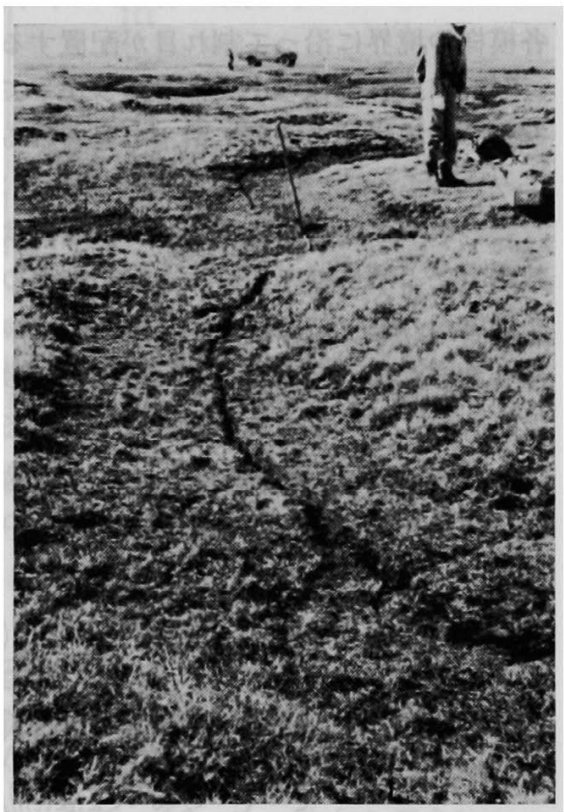

写真 9 構造土群の凹部に見られる 割れ目

バローはアラスカの北極海岸に位置し，アメリカ大陸の最北端である。年平均気温がー 12.4 ${ }^{\circ} \mathrm{C}$, 月平均気温が $0^{\circ} \mathrm{C}$ をこえてプラスになるのは，6，7，8の3力月にすぎない。最高気 温も高々 $10^{\circ} \mathrm{C}$ である。年間の降水量も $100 \mathrm{~mm}$ を少しこすだけで, 活動層の厚さは $40 \mathrm{~cm}$ を こえることはない。そのため立木が育たず, 苔, 地衣, スゲの類や, 柳, ポプラの小さな灌木 が植生としてあるだけで, ツンドラと云われる。永久凍土の厚さは $300 \mathrm{~m}$ をこ。地表近くは 洪積期堆積物でシルト質あるいは有機化したピートであるが，その下には砂質土がある。

タクトヤクタークは，カナダ北部のマッケンジー川のデルタ地帯にある。年平均気温は $-12.0^{\circ} \mathrm{C}$, 年間降水量 $130 \mathrm{~mm}$ とパローと殆ど変らない。永久凍土の厚さも $300 \mathrm{~m}$ をす程度 
である。マッケンジーという大きな川の デルタ地帯であるため, 到る所に水たま りがある。降水量の少ないわりには，水 の補給が多いということで，地面の凍結 に際しての凍土作用が著しい。そのため 永久凍土特有の典型的な地形が各所に見 られる。

\section{a. 構造土}

前述のアラスの底部又は側面に見られ るような規則的な地面模様のくりかえし で，一つの模様の幅は $10 \mathrm{~m}$ から $20 \mathrm{~m}$ で

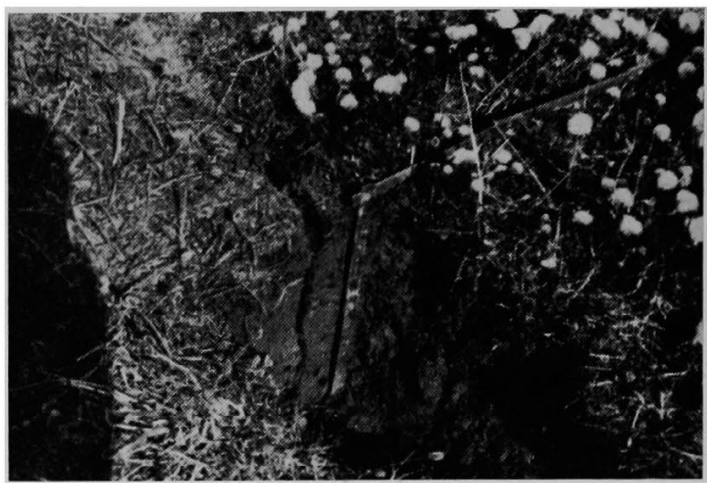

写真 10 割れ目の断面 ある。このようなものを構造土とよんでいる。バローやタクトヤクタークのようなツンドラ帯 では広く見られる。模様の特徵から，円形，網状，多角形，階段，線状の 5 種類に分類される。 各模様の境界に沿って割れ目が配置するものが多い。

写真 8 は各模様の中央部がもり上っている構造土群で，地表はイネ科の草に被われている。 写真 9 は模様間の凹部に沿って見られる割れ目である。写真10は割れ目の所の断面を掘り起し てみたところで, 約 $40 \mathrm{~cm}$ も地下深くまで達している。土質はシルト質である。

このような地表面に見られる割れ目は，冬期間に凍った活動層内の上下の温度差にもとずく 熱応力によるものである。一つの模様の大きさをきめる割れ目と隣りの割れ目との間隔 $x$ は， 活動層内の上下の温度勾配 $\mathrm{dT} / \mathrm{d} z$ と次の関係にある。 $x=\tau / 1 / 2 \alpha \mathrm{G}(\mathrm{dT} / \mathrm{dz})$ ，ここで， $\tau, \alpha, \mathrm{G}$ はそれぞれ凍土の剪断強度, 線膨張係数, 剪断弾性率である゙の。

バローに拈ける中央が凸になっている 構造土群の等高線図の一例を第 3 図に示す。高さは $20 \sim 50 \mathrm{~cm}$ で，凹部の幅は 1 3 $\mathrm{m}$ である。ひとつの構造土について，凸部の中心と凹部でボ ーリングを行なった。採取した試料について，断面構造や土質状況を観察し，更に含水比や現

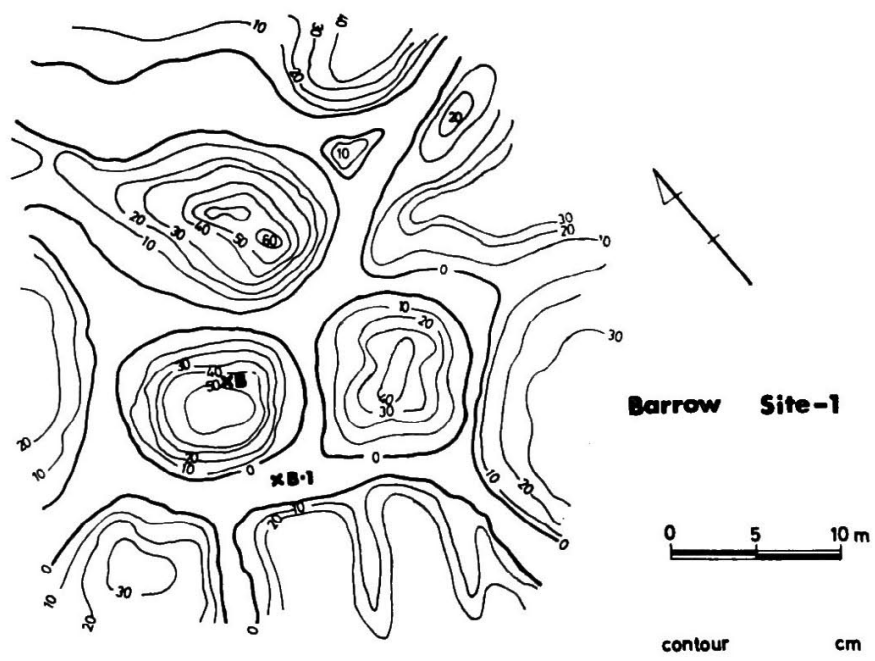

第 3 図 バローに打ける粠造土群の等高線図 


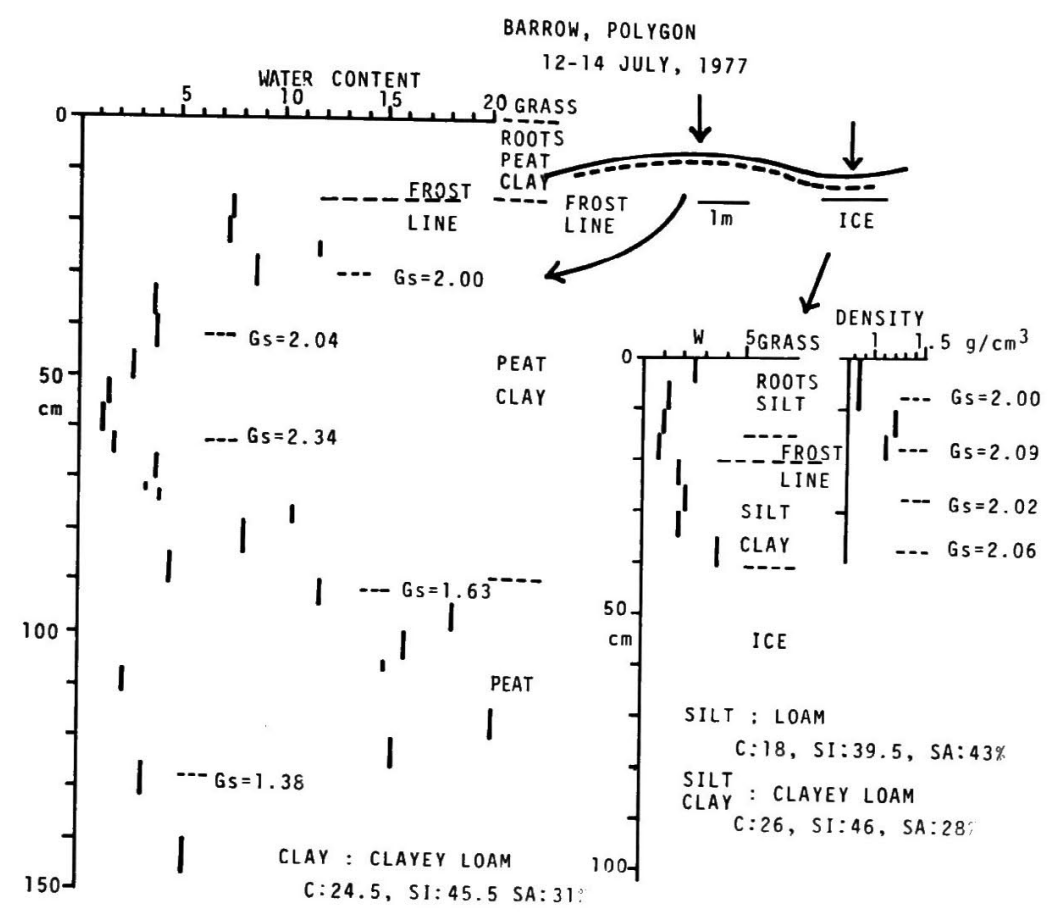

第 4 図 バローの構造土における断面観測の結果, 右上は形の模式図 破線は融解層の最 深位置を示す。左側は凸部, 右側は凹部における測定結果, $\mathrm{G}_{\mathbf{s}}$ は構成粒子の比 重, C, SI, SA はそれぞれ構成する粒子の粘土分，シルト分，砂分の\%である

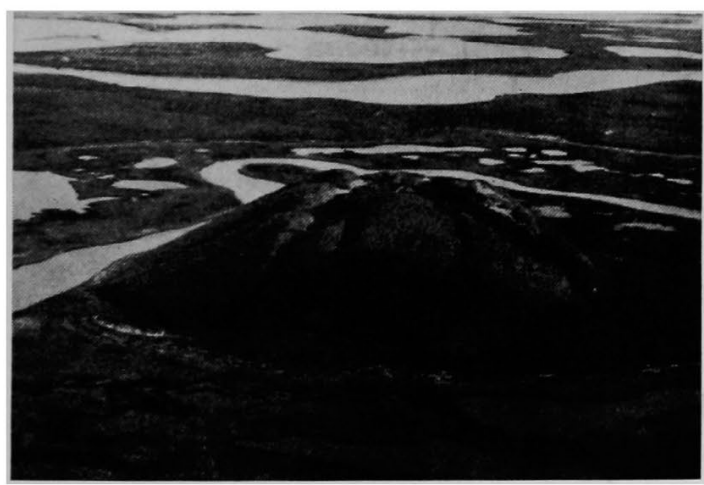

写真 11 イブークピンゴ, マッケシジーデルタ, タクトナクタークの部落から南南西 4.4 $\mathrm{km}$ にある 高さ $48 \mathrm{~m}$

場密度, 構成粒子の比重等の測定を行な った。昭和 52 年 7 月 $12 \sim 14$ 日の結果を第 4 図に示す。

この構造土の表面は, 厚さ $2 \sim 6 \mathrm{~cm}$ のイネ科の草で被われていた。凸部では

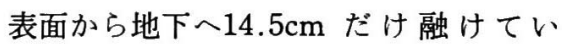
た。土質状態は，表面から地下 $13 \mathrm{~cm}$ ま でか゚草根，ピート，粘土の混合物で, $13 \mathrm{~cm}$ から $90 \mathrm{~cm}$ までがピートと粘土の 混合物, 以下氷を多く含むピートの順に なっていた。氷はレンズ状水のような無 垢の形ではなく，組織のなかに一様に分 散していた。その含水比は非常に大き

く，第 3 層では $2000 \% に も$ 達するものが見られた。

第 2 層に含まれていた粘土分を取り出して粒度分折をしたところ，粘土質ローム（粘土分 $24.5 \%$, シルト分 $45.5 \%$ ，砂分 $31 \%$ ）に分類された。又，地下 $100 \mathrm{~cm}$ 及び $130 \mathrm{~cm}$ にあピー

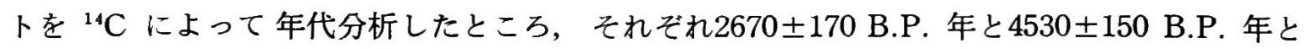




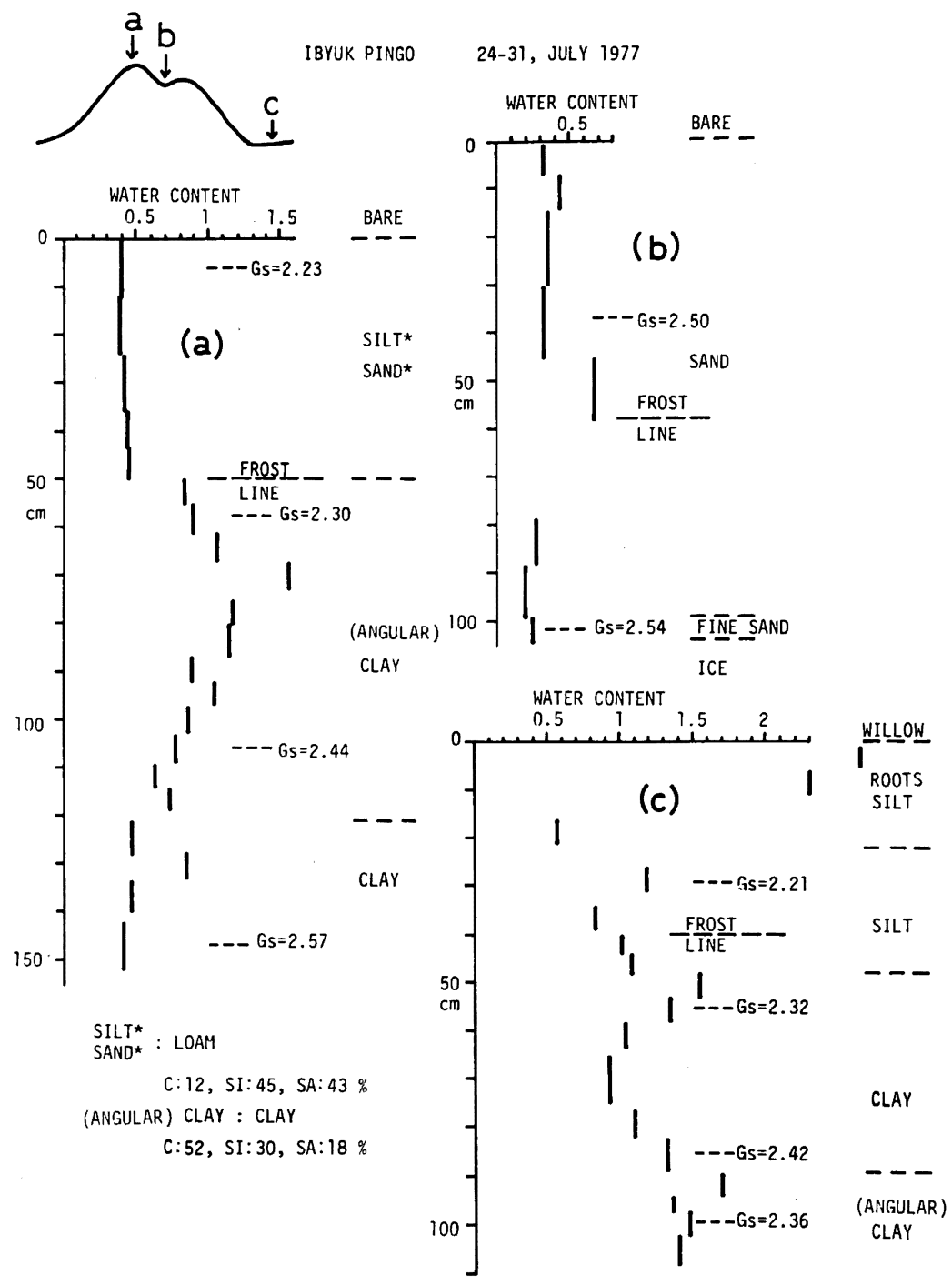

第 5 図 イプークピンゴの頂上 $\mathrm{a}$ ，クレーター b, 子もと c におけるボーリング試料 の解析結果

いう結果が得られた。

凹部は凸部のボーリング地点よりも $45 \mathrm{~cm}$ 低く，やはりイネ科の草に被われていた。融解は $20 \mathrm{~cm}$ の哚さに達していた。土質構造は, 地下 $16 \mathrm{~cm}$ までが草根とシルトの混合物， $16 \mathrm{~cm}$ か ら $41 \mathrm{~cm}$ までがシルトと粘土の混合物，以下は無垢の永であった。第 2 層は厚さ $1 \sim 3 \mathrm{~mm}$

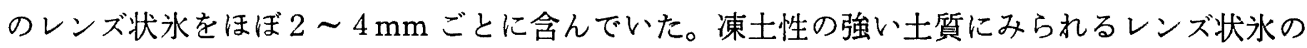
層と同じものである。含水比は高々 $180 \%$ 程度で, 凸部のピート層に比べると遙かに小さい。 このため凹部の方が融解が凸部よりも哚く進行したわけである。 


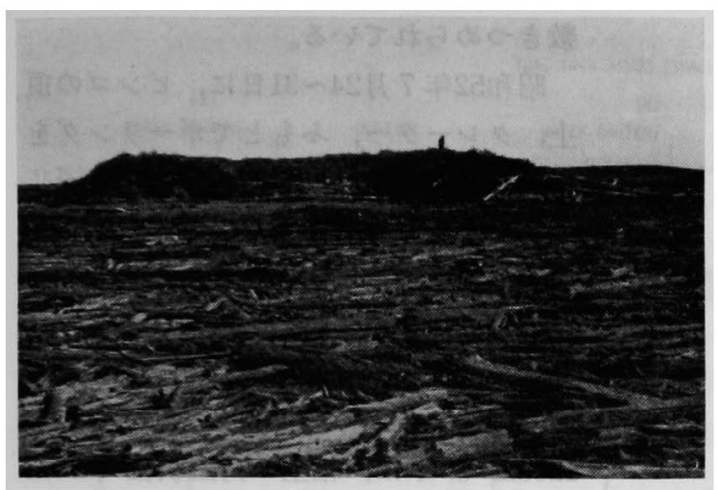

写真 12 高さ $5 \mathrm{~m}$ の小さなピンゴ タタトヤ クターク部落から南へ $2.5 \mathrm{~km}$

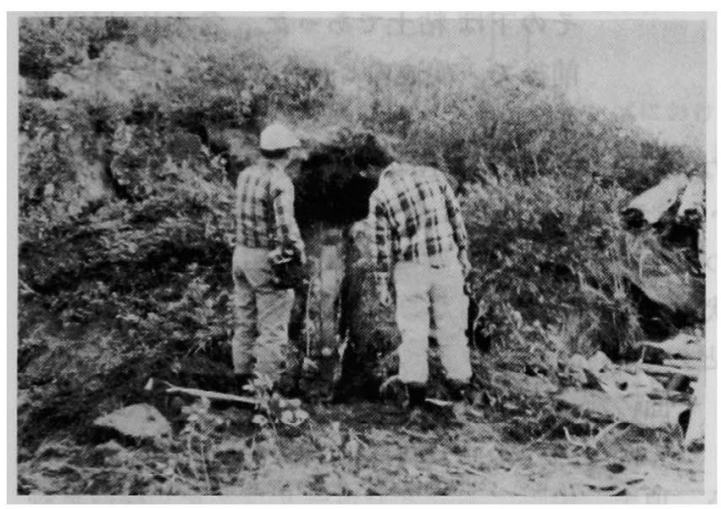

写真 13 崩れた表土の内部に氷塊が見える

第 1 層に含まれるシルトと第 3 層の粘 土・シルトの混合物を粒度分析したとこ ろ，ローム（粘土分 $18 \%$ ，シルト分 39.5 $\%$, 砂分 $43 \%$ ）と，粘土質ローム（粘土 分 $26 \%$, シルト分 $46 \%$, 砂分 $28 \%$ )に分類 された。

氷は多結晶水で，ひとつの結晶は水平 に $2 \sim 5 \mathrm{~mm}$, 鉛直に $2 \sim 5 \mathrm{~cm}$ の大き さで, 多数の気泡 (大きさ $0.5 \mathrm{~mm}$ ほど) を含んでいた。

構造土の凹部の下に無垢の氷が得られ たが,これは後に述べる氷楔と同じもの である。

\section{b. ピンゴ}

平らな湿地帯の中に盛り上る小丘で, 丘の内部には氷がつまっている。高さは 数メートルから数十メートルである。写 真11はイブークピンゴと呼ばれるもの で，海面からの高さは $48 \mathrm{~m}$ である。ピ ンゴはエスキモー語で円錘形の丘という 意味である。ピンゴはシベリアにもある が，ヤクート語ではブルグニヤルと呼ば れている。永久凍土地帯に存在するもの であるが，どこにでもあるというもので はない。氷の塊が盛り上る条件がそなわった所に出来る。特にマッケンジーデルタのタクトヤ クターク周辺に多く,ここはピンゴ公園と云われている。

ピンゴの成因として，土が凍るときに凍結線へ未凍土から水が吸いよせられて氷が析出す る，いわゆる凍上現象が考えられている。イブークピンゴは成因が次のように考えられてい る。始めに広く浅い沼があって，沼の水は冬に凍るが，その下に冬でも凍らない層があって， 更にその下に永久凍土層があったのが，あるとき，より寒い気候におそわれて，沼の水が完全 に凍り，その下の不凍層も凍り始めた。この不凍層は，上下前後左右の四周を凍土でつつまれ ているので, 凍結のときの凍上現象で体積増が起ると, 上部を押し上げて丘が出現する。上方 八水の析出が起るのであるが, この水が丘の内部に存在するのである。

イブークピンゴの頂上は裸地（さらさらとしたシルト質土）で，その下のクレーターでは, 表層砂地の裸地が半分ほどで, 他は, イネ科の草やヤナギの灌木が生い茂っていた。底部には 小さな沼もある。

斜面には, サマニヨモギ, トチナイソウのような草の他に, ヤナギやカンバの灌木が被って いた。特に溝の所には, ヤナギの高さ $1 \mathrm{~m}$ ほどの灌木が密集していた。ピンゴのふもとには, ガンコウラン, コケモモ, アカノウラシマッッジ等の日本の高山地帯で見られる草花が一面に 
TUK, THIN PINGO (SMALL)

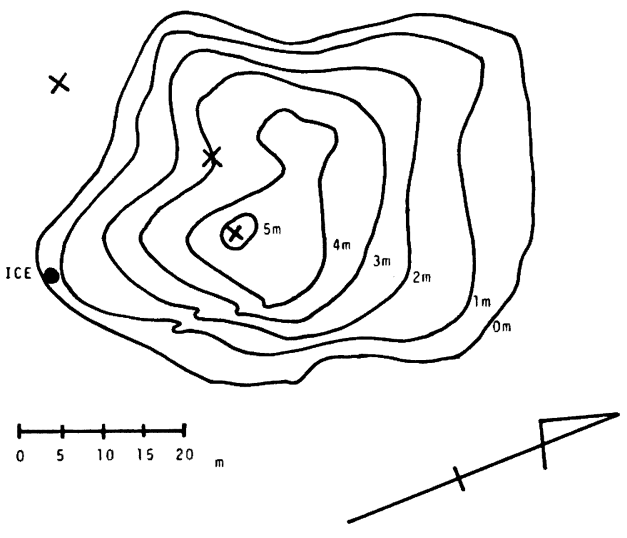

第 6 図 小ピンゴの等高線図 カケ印がボー リング点 丸印が氷塊の見えた所
敷きつめられている。

昭和 52 年 7 月 $24 \sim 31$ 日に, ピンゴの頂 上, クレーター,ふもとでボーリングを 行なった。前述のバローの構造土と同じ く種々の測定を行なった。その結果をま とめて第 5 図に示す。

頂上は裸地で, 融解も深く50cm にま で達していた。土質構造は $50 \mathrm{~cm}$ まで が，砂とシルトの混合物で， $50 \mathrm{~cm}$ から $120 \mathrm{~cm}$ までは, 粘土の角団状粒 $(1 \mathrm{~cm}$ 角位のもの）とその間を幅 $1 \sim 2 \mathrm{~mm}$ ほ どで埋める氷の網からなるもので，更に その下は粘土であった。含水比は $100 \%$ 前後で, 前述のピートに比べると非常に 小さい。

クレーターでは，ボーリングが裸地で行なわれた。表面から104cm までが砂でその下は氷 であった。融解も $58 \mathrm{~cm}$ の深さまで達していた。砂であるため, 含水比も非常に小さい。

ふもとでは，ボーリングがヤナギの灌木の所で行なわれた。融解は $40 \mathrm{~cm}$ まで達していた。 土質は頂上の第 2 層と同じく, 粘土の角団状粒と氷の網とからなるものであった。

イブークピンゴとは対照に，高さ $5 \mathrm{~m}$ ほどの小さなピンゴについてもボーリングを行なっ た。このピンゴは写真12に示されるように，一面の流木で被われた湿地のなかから突き出た形 になっている。測量地形図を写真13に示す。このピンゴの南側の斜面に表土が崩れて, 中味の 氷塊が見えていた。第 6 図がその状況である。頂上, 中腹, ふもとでボーリングをし採取試料 について解析を行なった。その結果を第 7 図に示す。

頂上の一部に裸地があったが，土質はイブークピンゴの頂上と同じくさらさらしたシルト質 土であった。しかし，沢山の小さな貝款（大きさ $1 \mathrm{~mm}$ ほど）を含み，昔は海浜であったこと が推測された。70cm ほど下からは，粘土の角団粒と氷の網からなる土質状態が現われた。こ の辺のピンゴの氷生成を引き起す土質は, この粘土のようである。

頂上の $40 \mathrm{~cm}$ 地下に，流木が埋まっていた。この流木はふもとを敷きつめているものと同し で, ピンゴの隆起によって, 一緒に持ち上げられたもののようである。流木の状態からせいぜ い100 年位前に流れ着いたもののようなので，このピンゴも成長を始めてから 100 年以内の若 いものらしい。昭和55年の調査では，この辺の解析の詳しいものが得られると思う。一方イブ ークピンゴの場合，成長を始めてから 1 万年前後とされている。

タクトヤクターク周辺には多くのピンゴがある。海岸にあるもののうちには, 海の波の侵蝕 をうけて，海側の半分ほどが削りとられたものがある(写真14)。

表面に亀甲状模様の構造土をつけたピンゴもある(写真15)。

\section{c. 水椟と集塊水}

活動層と永久凍土との境界面から下に向って頂点を下に，地中に楔を打ちこんだ形になって いる氷塊のことを氷楔と呼んでいる。上面の幅が $2 \mathrm{~m}$, 深さが $10 \mathrm{~m}$ 位のものを写真 $16 に$ 示す。 
TUK, TN!A PINGO (SMALL) 27-28, JULY 1977

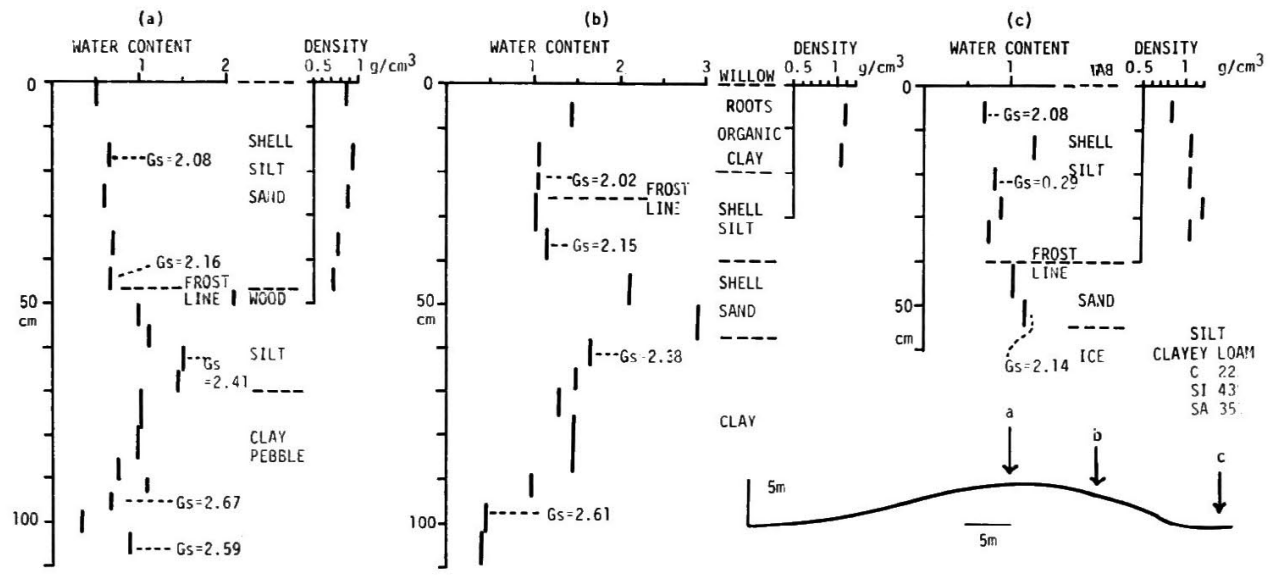

第 7 図 小ピンゴにおけるボーリンク゚の結果

(a) 頂上(裸地), (b ) 中腹(ヤナギの灌木)，(c ）ふもと(裸地)

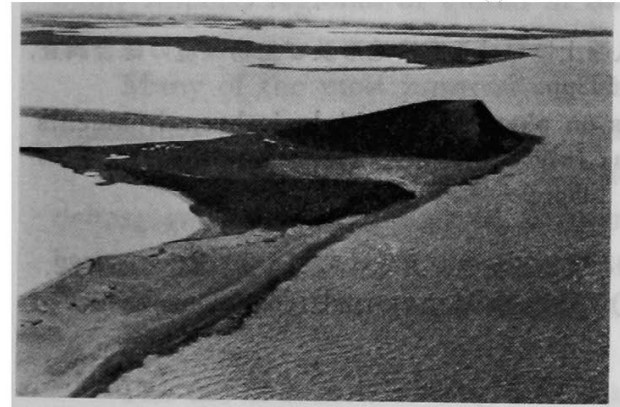

写真 14 タクトヤクターク部落から南西 $6 \mathrm{~km}$ の海岸にある半かけピン ゴ頂上の崖に氷が露出している

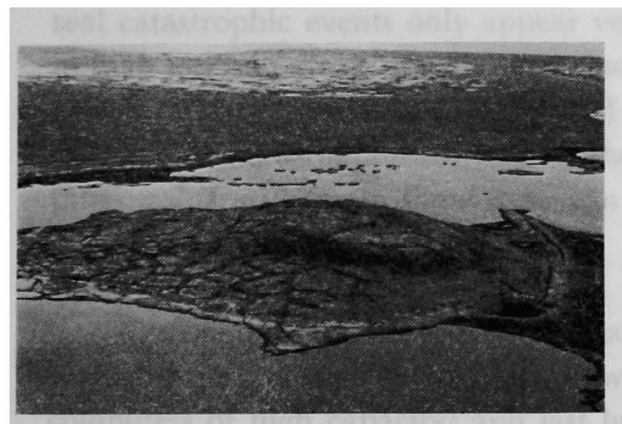

写真 15 山腹に構造土をつけるピンゴ

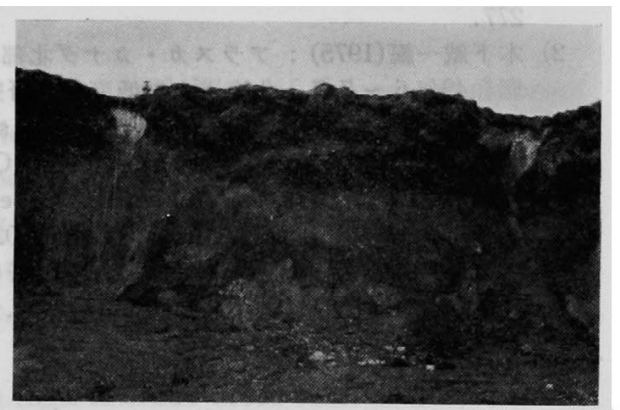

写真 16 タクトヤクターク部落から南西 $6 \mathrm{~km}$ の海岸に露出する氷楔群

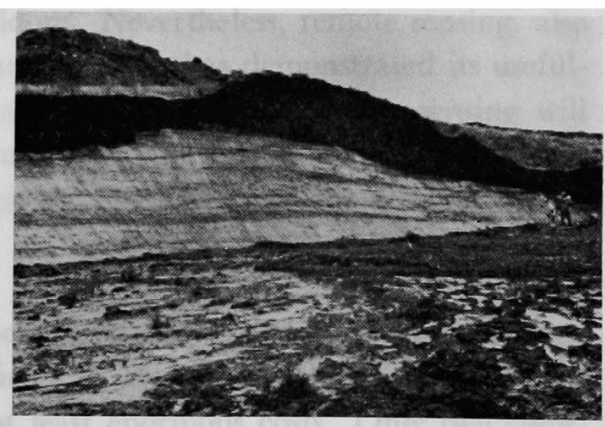

写真 17 タクトヤクターク部落から南西の $4 \sim 5 \mathrm{~km}$ にかけて, ほぼ $1 \mathrm{~km}$ にわたって露出する巨大集塊水 
この水は構造土凹部に位置するもので，たまたま海岸の侵触で，露出したものである。活動層 内の冬期間の温度差にもとずく熱応力がもとで出来るクラックに，夏の水がしみこむことで水

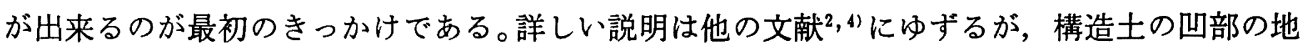
下深くに亀甲模様の氷楔が網目をなしているわけである。

集塊水は，海岸や湖沼の岸に露出する巨大な氷塊で，写真17に示されるように，高さ十数 $\mathrm{m}$ ，横幅は $1 \mathrm{~km}$ にもわたって，びったりと張りついている。タクトヤクターク周辺ではこの ような大承塊が到る所に見られる。しかし，すべての所にあるというわけではない。いったん 露出した氷塊は，夏期の融解で，毎年とけて行く。まだ露出せず地下に眠ったままでいる氷塊 も多くある。このような大氷塊がどうして出来たかについて色々の考えがあり，まだ定説がな いのであるが，アイソトープ等を使用する新しい手法により，徐々に解明されつつあると云え よう。

昭和54年11月，ノルデンショルドの日本周航100周年を記念するシンポジウムにおいて，筆 者等の永久凍土調查において見聞した若干の典型的な 永久凍土地形について 紹介した次第で ある。

\section{文献}

1）木下誠一・跉木義男 (1973)：シベリアヤクーックの永久凍土調査. 低温科学, 物理篇， 31, 271277.

2）木下誠一編(1975)：アラスカ・カナダ北部の永久凍土に扔ける寒冷地形及び生物環境の総合調查, 昭和 49 年 $6 \sim 7$ 月. 北海道大学低温科学研究所, 143pp.

3) Seiiti Kinoshita ed. (1978) : Joint studies on physical and biological environments in the permafrost, Alaska and North Canada, July to August 1977. Institute of Low Temperature Science, Hokkaido University. 149pp.

4) 木下誠一(1980) : 永久凍土. 古今書院, $202 \mathrm{pp}$,

5）木下誠一・酒井 昭(1973)：永久凍土地帯の森林の生態的特性. 日本生態学会誌, 24, 166-122.

6) Достовалов, Б. Н. и Кудрявцев, В. А. (1967) : Общее Мерзлотоведение. Издателбство Московского Университета. 403pp. 